\title{
Consumer Dispute Resolution: A Comparative Study between Indonesia and Common Law System Countries
}

\begin{abstract}
Kurniawan
Doi:10.5901/mjss.2017.v8n3p327

Lecturer of Faculty of Law, Mataram University, Indonesia

\section{Abstract}

Since 2001, based on the mandate of Article 49 paragraph (1) of Law no. 8 of 1999 on Consumer Protection, BPSK (Badan Penyelesaian Sengketa Konsumen/Consumer Dispute Resolution Institution) has been established based on Presidential Decree No. 90/2001 on the establishment of BPSK in several cities in Indonesia. In some countries that embrace the Anglo Saxon legal system, consumer dispute cases are resolved by an institution called The Small Claims Court (SCC) and The Small Claims Tribunal (SCT). The difference in settlement through three institutions is that BPSK is a formal institution which resolves small disputes with low-cost, but does not limit the size of the lawsuit filed by consumers. On the other hand, SCT provides clear restrictions on claims that can be filed by consumers. At the completion done by SCC, the assemblies that resolved the case come from active and retired judges, while in BPSK the assemblies come from government, businessman and consumer with different backgrounds.
\end{abstract}

Keywords: Consumer dispute, BPSK, SCT, SCC

\section{Introduction}

The advancement of science and communication and information technology currently supports the expansion of public space in conducting transactions of goods and/services to cross the boundaries of a country's territory, even offering goods and/or services by businessman is currently done through cyberspace (Internet) or better known as electronic commerce or e-commerce. Such condition on the one hand is very beneficial to the interests of consumers because the need for goods and/or services that are expected can be fulfilled and consumers are freer to choose various types of quality of goods and/or services based on their ability. But on the one hand, there are unavoidable problems that lead to disputes related to the transaction.

The development of dispute resolution over the past few years seems not only to the developing societies, but also to the lives of advanced or modern societies. Dispute resolution through Courts seems lack of full trust from the people, that they start looking for alternative of dispute resolution outside the court.

Since the 1970s in the United States there has been a tendency to "create" alternative dispute resolution institutions called Alternative Dispute Resolution (ADR) outside the general court process. The tendency of alternative institutions in the dispute resolution outside the court process relates to the view that not all problems or disputes that occur are suitable or can be resolved through the litigation. Munir (1997) pointed out that some disputes are less suitable to be resolved through court proceedings such as family disputes, controversy dispute between neighbors, demands that include a small amount of money and problems arising in the management of long-term trade relations.

Dispute resolution by court has proven to be much of a cause for dissatisfaction with the disputing parties and the wider community. Dissatisfaction of the community is expressed in the form of cynical, mocking, and blasphemous views on the performance of the court because it is deemed not to humanize the disputing parties, keep the disputing parties from justice, become the trade centre of judges' decision, and other blasphemies directed to the judiciary.

Based on the above description, the issue raised in this paper is how the comparison of consumer dispute resolution in Indonesia with countries that embrace common law system.

\section{Review on Related Literature}

The terms "dispute' and "conflict" are often used interchangeably, but essentially these two terminologies have different characteristics. Not every conflict causes disputes; otherwise every dispute is a conflict (Rohmad, 2008). In psychology studies, there are known types of psychiatric conflicts which are not legal disputes. This departs from the definition of conflict which is defined as the occurrence of two or more influs or antagonistic motives. An actual conflict usually speeds up a mental crisis and can be distinguished from root conflict that has arisen since childhood. Similarly, in the field of sociology it is also known group conflict and many more (Ali, 2004). 
Conflict or dispute is derived from the term "conflict", which means disputes or disagreements. Conflict or dispute happens between two or more parties. The community is currently faced with multiple dispute resolution options, in accordance with the level of significance and the fulfillment of their basic needs in seeing the conflict or dispute. Conflicts or disputes can be resolved through litigation, non-litigation or advocacy mechanisms (Syafa'at, 2006).

From some of the definitions above, it appears that conflicts are often referred to sociological studies, whereas legal and anthropological studies focus on dispute. Legal disputes are a standard term in jurisprudence, particularly in relation to civil cases to distinguish between criminal offenses in criminal cases.

Disputes are a universal phenomenon that can be found in every society with different backgrounds. How the dispute is resolved is absolutely different, meaning the disputing parties can take various action options with the aim that the dispute can be resolved (Kurniawan, 2011).

In UUPK no. 8 of 1999, it is said that consumer dispute is a part of the state administrative institutions that have the task to resolve disputes between businessman and consumers, in this case is BPSK. Article 1 point 11 of UUPK indicates that what is meant by "consumer dispute" is a dispute between businessmen and consumers.

\section{Research Methods}

The research is normative legal research that examines legislation, legal principles, and legal norms in order to obtain clear description of Resolve Consumer Disputes. Despite it is a normative research, this research is supported by field data (empirical).

\section{Result}

\subsection{Consumer Dispute Resolution in Indonesia}

In 1999, the Indonesian government enacted Law Number 30 of 1999 on Arbitration and Alternative Dispute Resolution, and Law no. 8 of 1999 on Consumer Protection (Undang-Undang Perlindungan Konsumen hereinafter abbreviated as UUPK). Afterward, some other laws were enacted such as employment as a non-court dispute resolution instrument in Indonesia.

Article 45 paragraph (2) of UUPK explains that consumer dispute resolution can be pursued through court or outside court based on voluntary choice of the disputing parties. Whereas in Article 47 of UUPK, it is argued that consumer dispute resolution outside the court is held to reach agreement in the form and amount of compensation and/or concerning certain actions to ensure that there will be no return or will not happen again the losses suffered by the consumers. In order to resolve consumer dispute outside the court, BPSK is established as described in Article 49 of UUPK, namely "the government establishes a consumer dispute resolution institution in the second level area (now the Regency or City) to resolve the consumer dispute outside the court" (Kurniawan, 2016).

BPSK was first inaugurated in 2001 based on Presidential Decree No. 90 of 2001 on the Establishment of BPSK in Medan, Palembang, Central Jakarta, West Jakarta, Bandung, Semarang, Yogyakarta, Surabaya, Malang and Makassar. Then in the same year (2001), the government through the Minister of Industry and Trade issued Ministerial Decree No. 350/MPP/Kep/12/2001 on the Implementation of Duties and Authorities of Consumer Dispute Resolution Institution (BPSK).

Consumer dispute resolution through BPSK based on UUPK no. 8 of 1999 and Decree of the Minister of Industry and Trade No. 350/MPP/Kep/12/2001 is described as follows:

\subsubsection{Application for Consumer Dispute Settlement}

Technically the application for Consumer Dispute Resolution is stipulated in Article 15-17 of the Decree of the Minister of Industry and Trade No. 350/MPP/Kep/12/2001 on the Implementation of Duties and Authorities of BPSK, in which the dispute resolution application form is filed orally or written to BPSK through the local BPSK Secretariat by the consumer, in case the consumer is harmed by the businessman.

\subsubsection{Procedure of Consumer Dispute Resolution through BPSK}

As part of alternative dispute resolution, the procedure for resolving consumer disputes through BPSK is very simple and is designed not in a formal atmosphere.

a. Application stage

Applications may be submitted through BPSK Secretariat, either written or orally. If the application is submitted in writing, BPSK secretariat will provide a receipt to the applicant. However, if the application is submitted orally, BPSK Secretariat will record it in a format which is specially designed. Furthermore, BPSK Secretariat 
will record the request and be affixed with the date and register number.

If the application is found to be incomplete (in accordance with the provisions of Article 16) or the lawsuit is not under the authority of BPSK, BPSK Chairman must reject the application. If the application is accepted (eligible), the consumer and businessman may choose and agree upon the means of settlement through conciliation, mediation or arbitration.

b. Trial Stage

Consumer dispute resolution through BPSK is conducted by the Assembly established under the Decree of BPSK Chairman and assisted by the Registrar. The Assembly shall be an odd number and shall consist of at least 3 (three) members of BPSK representing the elements of the Government (as chairman) and consumer and businessman as members, while the Registrar is appointed from the members of BPSK Secretariat.

If the application is received, the Chairman of BPSK shall summon the businessman in writing along with a copy of the request from the consumer no later than 3 (three) working days after the application for consumer dispute resolution is received correctly and completely. For the purpose of summoning the businessman, a letter shall be made containing: day, date, time and place of trial and obligation of businessman to provide an answer letter to consumer dispute resolution and submitted no later than the seventh day (seventh) from the day the application is received by BPSK.

The following will describe in detail the three ways of consumer dispute resolution through BPSK.

1) Trial by Means of Conciliation

Through conciliation, a conciliator will clarify the problems that occur and join in the midst of the parties, but his position is less active than a mediator in offering the options for the settlement of a dispute. Conciliation implies a unity of the parties where in the end the interests move closer and then it is received a satisfactory resolution for both sides (a measure of googwill). Reconciliation implies the unity of the parties to the dispute that they used to be friends or partners, now they are at odds/arguments. Different views among the parties must be met with care.

Article 28 of Kepmenperag No.350/MPP/Kep/12/2001 states in dispute resolution through conciliation the Assembly (conciliator) has the following tasks, which are:

a) Calling consumers and businessmen in dispute;

b) Calling witnesses and expert witnesses when necessary;

c) Providing a forum for disputing consumers and businessmen;

d) Answering the questions of consumers and businessmen, concerning legislation in the field of consumer protection.

During the dispute resolution process, evidence (goods and/or services, statement of the parties, statement of witnesses and or expert witnesses, letters and/or documents, other supporting evidences may be submitted by the Assembly at the request of the disputing parties.

2) Trial by Mediation

Settlement by means of mediation is not much different from conciliation, in which this way is taken on the initiative of either one party or all parties. The difference is BPSK Assembly is active as an intermediary and advisor. Basically, mediation is a process whereby the third party (neutral party) invites the disputing party to an agreed dispute resolution. Based on the boundaries, the mediator is in the middle and not in favor of either party. In accordance with its nature, mediation cannot be compulsory but can only happen if both parties voluntarily participate. The main role of mediator is to establish lines of communication and dialogue between the two parties that will lead to greater mutual understanding. In the end, an agreement will be created with nonviolent means, at least a relationship is created without conflict.

During the dispute resolution process, evidence (goods and/or services, statement of the parties, statement of witnesses and/or expert witnesses, letters and/or documents, other supporting evidences) may be submitted by the Assembly at the request of the disputing parties.

The result of the consensus which is the agreement between the consumer and the businessman in dispute is made in the form of a written agreement signed by the disputing parties and then submitted to the Assembly to make a decision of BPSK to strengthen the agreement.

3) Trial by Arbitration

Arbitration in dispute resolution is different from the two existing dispute resolution ways (mediation and conciliation). Assembly will resolve the consumer dispute by arbitration, in which the chairman of BPSK is not authorized to determine who will be the chairman of the assembly and members of the assembly. As for the authorities determining who sits in the assembly are the disputing parties, the parties may choose 
an arbitrator representing their interests. The consumer shall be entitled to vote freely one of the members of BPSK derived from the consumer element as an arbiter who will become a member of the assembly. Likewise, businessman is entitled to choose one of the BPSK members from the businessman as arbiter, who will become members of the assembly (Article 32 kepperperang No. 350/MPP/Kep/12/2001).

Furthermore, the arbiter of consumer's choice and arbiter of the businessman's choice shall collectively choose a third arbiter derived from the government elements of BPSK members who will become chairmen of the assembly. During the dispute resolution process, evidence (goods and/or services, statement of the parties, statement of witnesses and expert witnesses, letters and/or documents, other supporting evidences) may be submitted by the Assembly at the request of the disputing parties. Even in the process of resolving consumer disputes the burden of proof is on the businessman, the consumer also has the right to present evidence to support the lawsuit.

Having considered the statement of both parties on the subject matter of the dispute and considered the results of the substantiation and the request of the parties, the Assembly shall make BPSK Decision.

c. Decision Stage

The Assembly shall settle the consumer dispute not later than 21 working days since the lawsuit has been received by BPSK. The result of a consumer dispute resolution by way of conciliation or mediation is made in a written agreement signed by the consumer and businessman, further reinforced by the decision of the Assembly signed by the Chairman and Members of the Assembly. The Assembly's decision on conciliation and mediation does not contain administrative sanctions. The result of consumer dispute resolution by arbitration is made by the decision of the Assembly signed by the Chairman and Members of the Assembly. The Assembly's decision in arbitration contains administrative sanctions. The decision of the Assembly may be based on deliberations to reach consensus, but if it has been sought in earnest and does not produce a word of consensus, then the decision shall be taken by a majority vote. The decision of the Assembly is referred to as the decision of BPSK (Article 38 of Minister of Industry and Trade No. 350/MPP/Kep/12/2001).

The scheme of consumer dispute resolution through BPSK can be described as in the scheme below.

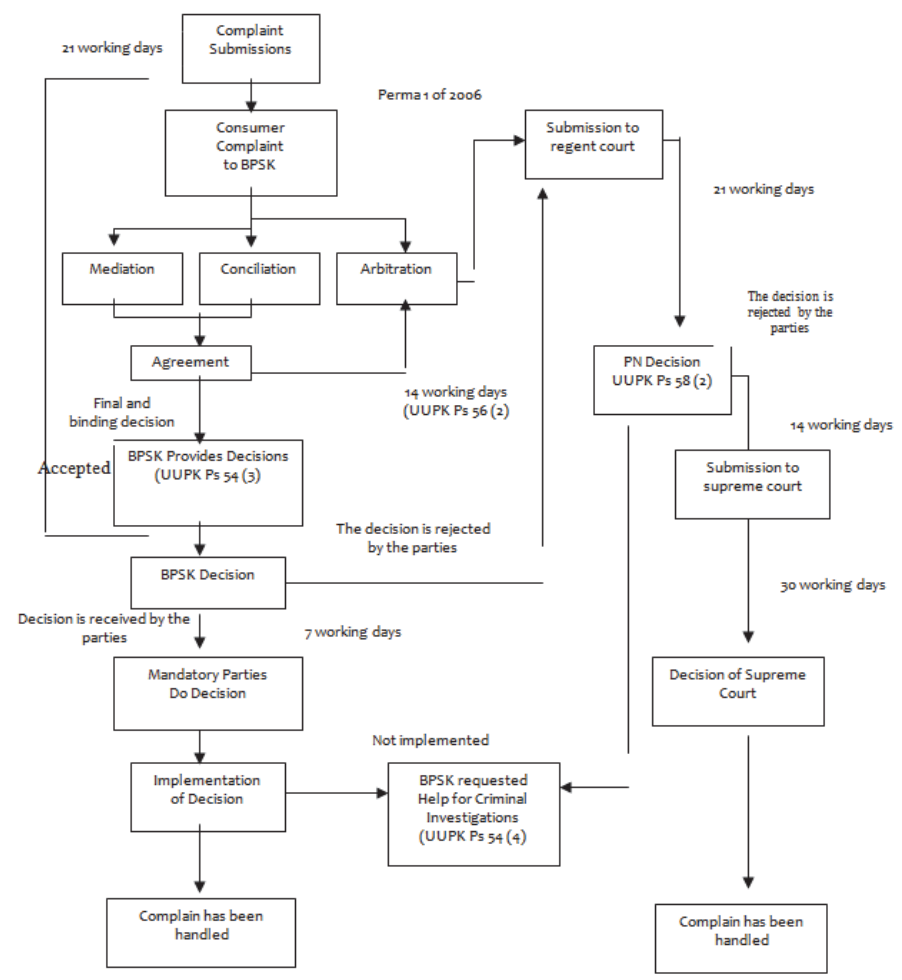

Figure 1. Consumer dispute resolution process through BPSK 


\subsection{Consumer Dispute Resolution in Common Law System Countries}

In some Common Law System countries, consumer dispute resolution cases are resolved by institutions called The Small Claims Court, The Small Claims Tribunal, The Consumer Claims Tribunal and The Market Court.

Dispute resolution institutions are generally located in countries, such as:

a. The Small Claims Court in the United States and Singapore;

b. The Small Claims Tribunal in New Zealand, Singapore and Hongkong;

c. The Consumer Claims Tribunal in Australia;

d. The Market Court in Finland and Sweden; and

e. Consumer Disputes Redressal Agencies/District Forum in Indian Country.

From the four terms of dispute resolution, in general it can be grouped into 2 (two), which are:

\subsubsection{Small Claims Court (SCC)}

Small claims court dispute resolution model is a simple settlement system that is a single judge with no jury and simple proof. In this model, legal advisor is generally not used, but it is possible that relative, friend or lay representative assistance can be requested from Citizens Advice Bureau, who has trained advisers who are ready to assist those who file small claims.

\subsubsection{Small Claims Tribunal (SCT)}

Small Claims Tribunal is used to refer to a small-scale civil claims institution in a simple, informal, quick and low-cost way. Dispute resolution institutions are commonly found in countries that adhere to the Anglo Saxon or common law legal system such as: New Zealand, Hong Kong and Singapore.

In Singapore, on the settlement of a consumer dispute the Small Claims Tribunal acting as a judge is a Barrister or Solicitor as Referee. The tribunal members who lead the proceedings are referred to by the term "President" and the decision is referred to as "decision" or "settlement" or "award". Singapore as a country that uses The Small Claims Tribunal provides restrictions on the lawsuit that can be filed, i.e. the loss suffered by consumers is not more than $\operatorname{Sin} \$$ 2000 (Kian \& Chim, 1986).

The fundamental difference between the two types of dispute resolution is the Small Claims Court (SCC) is permanent while the Small Claims Tribunal (SCT) is temporary or ad hoc. It appears in the authority to examine and adjudicate or, in other words, the person who acts as a judge on the Small Claims Court is actually exercised by a presiding judge so that its judgment is called judgment (Nugroho, 2008).

\subsection{Differences in Dispute Resolution through BPSK and SCC and SCT}

Consumer dispute resolution in Indonesia through BPSK has differences with consumer dispute resolution in common law system states with Small Claims Court and Small Claims Tribunal. Such differences as seen in the Indian state are as follows:

a. Consumer dispute in India is only possible one time appeal whereas BPSK is possible twice appeal namely, objection to the District Court and appeal to the Supreme Court;

b. Members of consumer dispute settlement assembly in India are a combination of active judges and retired judges and community components, while the BPSK assemblies consist of government, consumer and businessman.

c. In India the level of dispute resolution is associated with the amount of the value of the lawsuit, while in Indonesia it is not associated with the limit of the number of charges. This means that BPSK institutions are obligated to resolve disputes with unlimited claims. The duties and obligations of BPSK are to serve all consumer disputes through mediation, conciliation and arbitration. This shows that BPSK institution is not a Small Claim Court model to resolve consumer disputes with small values, such as the original intention of BPSK establishment.

d. Consumer dispute resolution institutions in India have the duty and authority to solve consumer disputes, while BPSK not only resolves consumer disputes, but also has the authority to supervise the standard clause. The researcher argued that of one of the problems that arise in the system of consumer protection is the unclear system of authority among institutions. As the result, in the future the task of supervision of the standard 
clause, which is preventive (not a dispute), would be more appropriate if it becomes the full authority of the BPKN (Badan Perlindungan Konsumen Nasional/National Consumer Protection Agency).

For more details, the differences between consumer dispute resolution in Indonesia through BPSK and consumer dispute resolution in common law system states through Small Claims Court (SCC) as applicable in India will be elaborated in below table.

Table 1: Differences BPSK with Small Claims Court (SCC) in India

\begin{tabular}{|l|l|l|}
\hline No & BPSK & Small Calims Court (SCC) \\
\hline 1. & $\begin{array}{l}\text { BPSK is allowed to make two appeals namely, objection } \\
\text { to the District Court and appeal to the Supreme Court }\end{array}$ & Consumer dispute in India is only possible for one appeal \\
\hline 2. & $\begin{array}{l}\text { BPSK Assembly consists of government, consumer and } \\
\text { businessman }\end{array}$ & $\begin{array}{l}\text { Member of consumer dispute resolution assembly in India is a } \\
\text { combination of active judges as well as retired judges and community } \\
\text { components }\end{array}$ \\
\hline 3. & BPSK is not associated with demand limit. & $\begin{array}{l}\text { In India the level of dispute resolution is associated with the amount of } \\
\text { the value of the lawsuit }\end{array}$ \\
\hline 3. & $\begin{array}{l}\text { BPSK in addition to resolving consumer disputes also } \\
\text { has the authority to supervise the raw clause }\end{array}$ & $\begin{array}{l}\text { Consumer dispute resolution institutions in India have the duty and } \\
\text { authority to merely resolve consumer disputes }\end{array}$ \\
\hline
\end{tabular}

Source: primary data obtained by the researcher

The general differences between consumer dispute resolution in Indonesia through BPSK and dispute resolution in common law system countries through Small Claims Tribunal (SCT) applicable in Common Law countries are as follows:

Table 2: Differences between BPSK and Small Claims Tribunal (SCT)

\begin{tabular}{|l|l|l|}
\hline No & BPSK & Small Claims Tribunal (SCT) \\
\hline 1. & $\begin{array}{l}\text { BPSK is a small, formal, and low cost consumer } \\
\text { dispute resolution institution. }\end{array}$ & $\begin{array}{l}\text { SCT is a small-scale civil claims institution with simple, informal, fast and low } \\
\text { cost way }\end{array}$ \\
\hline 2. & BPSK is permanent & Small Claims Tribunal is temporary or ad hoc \\
\hline 3. & $\begin{array}{l}\text { The judge is a member of BPSK coming from } \\
\text { government, consumer and businessman. }\end{array}$ & The judge is a Barrister or Solicitor as Referee. \\
\hline 4. & $\begin{array}{l}\text { Members of BPSK who lead the trial are called } \\
\text { the Chairman of BPSK Assembly. }\end{array}$ & $\begin{array}{l}\text { The tribunal members who lead the proceedings are referred to by the term } \\
\text { "President" in which their decision is referred to as "decision" or "settlement" } \\
\text { or "award". }\end{array}$ \\
\hline 5. & $\begin{array}{l}\text { BPSK does not impose restrictions on the value } \\
\text { of the losses or claims that may be filed. }\end{array}$ & $\begin{array}{l}\text { The Small Claims Tribunal provides restrictions on the lawsuit that can be } \\
\text { filed i.e. the loss suffered by consumers is not more than Sin \$ 2000. }\end{array}$ \\
\hline 6. & $\begin{array}{l}\text { BPSK resolves cases of consumer disputes and } \\
\text { business offenses against the standard clause. }\end{array}$ & $\begin{array}{l}\text { There are limits on what cases can be filed or cannot be submitted to the } \\
\text { Small Claims Court or the Small Claims Tribunal }\end{array}$ \\
\hline 7. & $\begin{array}{l}\text { The cost of the case is charged to the } \\
\text { businessman. }\end{array}$ & \begin{tabular}{l} 
Low case fees even in some countries are released \\
\hline
\end{tabular} \\
\hline
\end{tabular}

Source: primary data obtained by the researcher

From the differences expounded above, it appears that consumer dispute resolution in Indonesia through BPSK is inconsistent; this is due to several things as follows:

a. Compared with Small Claims Court (SCC), BPSK has a lot of tasks. This might be the causes of BPSK to become unfocused in carrying out its work. Therefore, in the future the task of BPSK should merely be focused on dispute resolution.

b. BPSK is a small, formal, and low cost consumer dispute resolution institution. However, in its implementation BPSK does not provide restrictions on the value of losses or claims that can be submitted to BPSK. On the contrary, the Small Claims Tribunal which provides clear restrictions on the lawsuits that can be filed, for example in Singapore the consumer losses are handled no more than 2000 dollars.

c. At the Small Claims Court (SCC), the Assembly resolving cases comes from the elements of active and retired judges, while in BPSK the assemblies come from government, business and consumer with different backgrounds. The researcher argued in the future members of BPSK Assembly should come from 
academicians, businessman and consumers with law degree background, so that they will better understand the duties in the field of justice.

\section{Conclusion and Suggestions}

\subsection{Conclusion}

From the discussion above, it can be drawn a conclusion that the difference of consumer dispute resolution through BPSK in Indonesia with consumer dispute resolution through SCC and SCT in common law system countries can be seen from institutional system, boundary value of lawsuit, and origin of assembly (judge). BPSK is a small, formal and low cost consumer dispute resolution institution, but it does not limit the size of the lawsuit filed by consumers, whereas SCT in Anglo Saxon law countries is a dispute resolution institution for small-scale civil claims with simple, informal, quick and low-cost ways and provide clear restrictions on claims that can be filed by consumers. At the completion of SCC model, the assemblies that resolve the case come from the elements of active and retired judges, while in BPSK the assemblies that handle the case come from government, businessman and consumer with different backgrounds.

\subsection{Suggestions}

BPSK in Indonesia is an adoption of the Small Claim Tribunal (SCT) model that is already running in developed countries or common law system countries. However, in its implementation many SCT concepts are not applied to BPSK. In the future, BPSK should apply the provisions as contained in the SCT, especially regarding the limitation of the value of consumer charges. In addition, members of BPSK should come from elements outside the government to be more independent and should be a Bachelor of Law.

\section{References}

Ali, A. (2004). Sosiologi Hukum: Kajian Empiris Terhadap Pengadilan. Iblam.

Suparman, E. (2003). Jurisdiksi Pengadilan Negeri Terhadap Forum Arbitrase Dalam Penyelesaian Sengketa Bisnis Berdasarkan Undang-undang Nomor 30 Tahun 1999. Research Report. Dana DIK UNPAD 2003.

Moore, C.W. (1996). The Mediation Process: Practical Strategies for Resolving Conflict. 2nd ed. San Francisco: Jossey-Bass Publishers. Catherine Tay Swee Kian and Tang See Chim, (1986). Your Right as a Consumer. Time Book International Singapura Press.

Ihromi. (1993). Beberapa Catatan Mengenai Metode Sengketa yang digunakan dalam Antropologi Hukum, dalam Antropologi Hukum; Sebuah Bunga Rampai. Obor Foundation. Jakarta.

Kurniawan. (2011). Hukum Perlindungan Konsumen, Problematika Kedudukan dan Kekuatan Putusan BPSK. UB Press. Malang.

--, (2016). Hukum Perlindungan Konsumen. Pustaka Bangsa. Mataram-NTB.

Marbun, B.N. (2006). Kamus Hukum Indonesia. Volume I. Pustaka Sinar Harapan. Jakarta.

Munir, M. (1997). Penggunaan Pengadilan Negeri Sebagai Lembaga untuk Menyelesaikan Sengketa dalam Masyarakat, Kasus Penyelesaian Sengketa yang Berkaitan Dengan Tanah dalam Masyarakat di Kabupaten Bangkalan Madura. Doctoral dissertation, University of Airlangga. Surabaya.

Nader, L. and Todd, H. (1978). Introduction to the Disputing Process: Law in Ten Societies (New York: Columbia University Press.

Nugroho, S.A. (2008). Proses Penyelesaian Sengketa Konsumen Ditinjau Dari Hukum Acara Serta Implementasinya. Kencana, Jakarta. Rohmad, A. (2008). Paradigma Resolusi Konflik Agraria. Walisongo Press. Semarang.

Simorangkir, J.C.T., et.al. (1995). Kamus Hukum. Moulds 5th. Bumi Aksara. Jakarta.

Syafa'at, R. (2006). Mediasi dan Advokasi Konsep dan Implementasinya. Agritek YPN Malang cooperated with SOFA Press. Malang. 
ISSN 2039-2117 (online)

ISSN 2039-9340 (print)
Mediterranean Journal of Social Sciences MCSER Publishing, Rome-Italy
Vol 8 No 3

May 2017 